\title{
North Sea research: where might it go?
}

\author{
S. A. Gerlach \\ Institut für Meereskunde Kiel; Düsternbrooker Weg 20, D-24105 Kiel, Germany
}

\begin{abstract}
Seven research suggestions are discussed: the phenomenon of the rare species, the life conditions of meiofauna in suboxic sediment layers, the part-time dormancy of animals and bacteria in the sediment, the importance of lateral advection for the flux of organic matter to the benthos, the selection of sites representative of larger North Sea regions, the selection of monitoring stations, and the importance of viruses, bacteria and other parasites for the North Sea ecosystem.
\end{abstract}

\section{INTRODUCTION}

During the past 25 years when I was the director of a research department or of a marine research institution, I often had to work out medium-term research plans. Of course I always included, in a selfish way, (1) projects which fitted anyway into my group's research capacities and, (2) projects which I hoped could be looked upon favourably by the 'soft' funding agencies. In the 'seventies, I had to chair a group of German scientists. We identified in a more general way the marine biology research topics for the 'eighties (Gerlach, in Hempel \& Meyl, 1979): (1) Light-nutrient-phytoplankton interaction, (2) Food-chains and food-conversion, (3) Role of dissolved organic substances, (4) Remineralization, (5) Development of models, and (6) Spatial and temporal variability.

The 'eighties are now past. Worldwide, much progress has been achieved on all of the above topics. But some unforeseen findings occurred too, for example, the discovery of hydrothermal vents and cold seeps, and the discovery of hydrogen sulphide and methane, as energy sources which are independent of sunlight. These findings document how limited our capacity is to look into the future. My suggestions for future North Sea research are strictly personal; I shall now discuss some unsolved scientific questions.

\section{RARE SPECIES}

Forty-three years ago, in 1949, I started my North Sea career at the almost forgotten Zoologische Station Büsum, a private station run by Sebastian Müllegger, who was pharmacist in the town of Heide. In the 'twenties, this station even published a periodical, the "Schriften für Süßwasser und Meereskunde, Büsum". I sampled the sandy beaches and the intertidal flats of Büsum, Amrum and Sylt. I described the spatial distribution of nematodes on the German coasts (Gerlach, 1953) and identified 140 different nematode species (Gerlach, 1954). At that time I was a student of Professor Dr. Adolf Remane in the Zoological Institute of Kiel University. The term ecology meant, to us, to find out which 
species of animals live where, and the environmental factors which control their distribution. I was happy when I encountered a rare species, and I rather despised the common ones. I described (from the North Sea intertidal) no less than 19 nematode species which were new to science.

First suggestion for future North Sea research: Find out why rare species are rare. Do they just inhabit rare environments? If so, we should develop a monitoring strategy for rare environments. Small and rare species have no ecosystem importance in terms of energy flow, but they are a reality and they had survived millions of years, before I discovered some of them. I think it is an important research topic to find out how rare species have managed to survive. And will they survive? Or will they be the first to die out when the environment is polluted or otherwise changed?

\section{MEIOFAUNA AND THE SEDIMENT ENVIRONMENT}

When I became director of the Bremerhaven Institute of Marine Research, I turned my attention to ecosystem research. Based upon some experiments on the life cycles of nematodes, I published, in 1971, a Paper "On the importance of marine meiofauna for benthos communities" which has recently been distinguished as a citation classic (Gerlach, 1987) because many marine ecologists have cited the following from this Paper as fact: that meiofauna animals have 3 generations per year, and that the ratio of annual production to biomass $(\mathrm{P} / \mathrm{B})$ is about 10 . These generalizations are based on experiments with a few meiofauna species which can easily be cultivated. Most of them live in the "Aufwuchs" or on the sediment surface. But the majority of softbottom nematode species live in the suboxic, or even in the anoxic, layers of the sediment. Unfortunately, up to now we have not succeeded in cultivating these species. Accordingly, we do not know anything about their life-span and rate of production.

Second suggestion for future North Sea research: Develop culture techniques for organisms, meiofauna and bacteria, which live in suboxic environments or in those redox discontinuity layers where oxic and anoxic conditions alternate.

\section{DORMANCY IN THE BENTHOS}

In the 'seventies I tried to understand how the benthos of a 35-metre silty sand station off Helgoland works (Gerlach, 1978). I calculated that sediment bacteria only have to divide 20 times per year in order to supply the food demands of the zoobenthos. In a culture, however, sediment bacteria duplicate much more often. My conclusion is: most sediment bacteria remain dormant until the environmental conditions in their surroundings improve. Such improvement could come from any disturbance, from the sedimentation of a plankton bloom, from erosion by waves or currents, or by macrofauna bioturbation. In 1980, when I applied for the Professorship of Benthos Ecology at the Kiel Institute of. Marine Science, I lectured on the sluggishness of benthos animals. My guess is that not only bacteria, but macrofauna animals too, sleep (reduce their metabolism) between short periods of activity. Maybe, sleeping is not the right term, but the term dormancy means just the same.

Third suggestion for future North Sea research: Ecosystem models should take into consideration that benthic organisms do not work hour by hour at full 
speed. It is not legitimate to simply multiply the results of physiological experiments by 24 hours per day and by 365 days per year. Instead, find out the cyclic or aperiodic life patterns of benthic organisms.

\section{LATERAL ADVECTION}

In the 'seventies, John Steele elaborated his famous North Sea model (Steele, 1974). It was one of the first attempts to consider the North Sea as an entity. Steele's group quantified total fisheries yield, fish biomass and fish food demand for a total of $520000 \mathrm{~km}^{2}$ North Sea and calculated data per $\mathrm{m}^{2}$. The model is supplemented with other data per $\mathrm{m}^{2}$, for example, with my 1971 meiofauna production estimates. But fluxes cannot be realistic in such a model, because of lateral advection.

Benthic organisms receive organic particles, their food, not only by vertical sedimentation from surface waters, but also enjoy some import from shallower regions by lateral advection (Graf, 1992). Evidence is increasing that repeated events of sedimentation and resuspension cause a step-by-step transportation of particles from shallower areas of the North Sea downslope to the deeper depressions, and to a final sink in the Skagerrak. This transportation can be modelled (Puls, in Sündermann \& Degens, 1989). Incidentally, the horizontal current velocity of the water above the sea bottom is much higher than the vertical sinking speed of phytoplankton and other particles.

Fourth suggestion for future North Sea research: Abandon the water column concept and take into consideration that lateral advection contributes significantly to the energy flow in the benthos. Develop methods to quantify the import and export of particles by lateral advection. Realise that the North Sea belongs to the neritic province. There is a flux from the benthos back to the water column and also some loss of particles to the deep sea.

\section{REPRESENTATIVE STATIONS}

Recently, I had to review the classification of 260 macrofauna stations by the ICES Benthos Ecology Working Group (Künitzer et al., 1992) into the following assemblages:

- the deep sea assemblages of the Skagerrak and the Norwegian Trench;

- the offshore assemblages at 70-200 m depth in the Northern and Central North Sea, where bottom water temperatures remain below $10^{\circ}$ in summer;

- the assemblages at 30-70 m depth in the Central and Southern North Sea where the fluctuations of bottom water temperatures are greater;

- the coastal assemblages in regions shallower than $30 \mathrm{~m}$ in the Southern North Sea where bottom water temperatures rise to $16-17^{\circ}$ in summer, but may drop to below zero in very cold winters.

This classification supplements and refines earlier benthos work in the North Sea, and should be used to subdivide the North Sea in a better way than the traditional ICES sub-regions.

Fifth suggestion for future North Sea research: Identify sites where plankton, fish, benthos and environmental factors are representative of a larger sub-region of the North Sea. Collect data and construct a model for each of these subregions and define the horizontal fluxes between the sub-regions. Such sub-regional 
models are fundamental, among other things, to our understanding the distribution patterns of cadmium in hermit crabs (Karbe, in Sündermann \& Degens, 1989).

\section{CHANGES IN TIME}

The observation of oxygen deficiency in the bottom water of the German Bight, in 1981 and in some later years, started a heated discussion on eutrophication. I headed a working group on eutrophication (Gerlach, 1990); we discussed different time series in order to decide whether (1) increased input of nutrients, or (2) changed weather conditions, or (3) both factors were responsible for the effect. The Helgoland Reede time series is famous because the series was started in 1962, and because sampling has been carried out every working day since then.

The general conclusion from the Helgoland Reede time series is: variation between years was extremely high. Part of this variation is certainly, (1) due to the unfortunate situation of Helgoland Reede station at $6 \mathrm{~m}$ water depth in the current-swept sound between Helgoland and Duene, (2) due to the situation of Helgoland at the border of stratified and mixed water masses in summer, and (3) due to the frequently-occurring intrusion of coastal water masses which are more or less mixed with river water. Therefore Helgoland Reede station is not representative of a larger North Sea area.

Sixth suggestion for future North Sea research: Re-organize monitoring. Only those stations should be monitored which are representative of both water and benthos and of the relation between the two. Zooplankton grazing should be included. Sedimentation traps should be installed in order to analyse the vertical transport of particles to the seabed. Distinguish between small benthos which reacts quickly to changes, and large benthos animals which grow to an age of several years and develop their own indigenous population dynamics. Protect monitoring stations against the impact of fisheries, by creating nature-conservation areas.

Unfortunately, scientists, institutes and agencies do not like to give up an existing monitoring station. But existing monitoring activities were originally not invented with the aim of verifying ecosystem models. However, ecosystem research urgently needs representative monitoring stations in order to verify the different models produced. If the model cannot simulate the same reactions of the ecosystem as are observed by monitoring, the model is wrong or incomplete.

\section{PARASITES}

In 1983 I accidentally learned about a nearly-forgotten case of paralytic shellfish poisoning which happened 1880-1887, in the dock-harbour of Wilhelmshaven (Gerlach, 1985). Since then I have been fascinated by toxic phytoplankton. In May 1988, I was bothered by the coincidence of two events: by the bloom of the toxic flagellate, Chrysochromulina polylepis in the Skagerrak, which killed caged salmon and epifauna down to $15 \mathrm{~m}$ water depth, and by the first evidence of a seal mortality nearby in the Kattegat. I tried to connect the seal mortality with the toxic phytoplankton bloom (Gerlach, 1989), but without success. The seals died from distemper, at least in the later phase of the epidemic.

In the long run, both host and parasite live in co-existence. But on the short timescale a parasite sometimes gets out of control and reduces the population of its host. 
Recently, viruses have been identified in every sample of sea water analysed. The hosts of these viruses are largely unknown. But there is reason to assume a great impact upon marine bacteria and phytoplankton.

Seventh suggestion for future North Sea research: Look for parasites, including viruses, and identify their effects on North Sea bacteria, plants and animals. It is time to realize that, among other parameters, parasites are ecological factors that may control populations.

\section{CONCLUSION}

I have confronted you with seven suggestions for future North Sea research, and this is a very special selection based upon my personal experience. A vast store of knowledge has been achieved in the fields of Marine Biology and Biological Oceanography over the past 100 -year period, but there still remains more for the future to be explored. Singular events have occurred which have never before been observed by scientists, for example a Chrysochromulina bloom, a seal mortality etc. The public wants an immediate answer as to the causes of these phenomena, and whether they might be man-made. However, marine science has to learn from case to case, which is a slow procedure. There are not only rare species in the sea, but also rare high-energy events that happen from time to time. We must be patient.

\section{LITERATURE CITED}

Gerlach, S. A., 1953. Die biozönotische Gliederung der Nematodenfauna an den deutschen Küsten. - Z. Morph. Ökol. Tiere 41,411-512.

Gerlach, S. A., 1954. Die freilebenden Nematoden der schleswig-holsteinischen Küsten. - Schr. naturw. Ver. Schlesw.-Holst. 27, 44-69.

Gerlach, S. A, 1978. Food-chain relationships in subtidal silty sand marine sediments and the role of meiofauna in stimulating bacterial productivity. - Oecologia 33, 55-69.

Gerlach, S. A., 1985. Kann es beim Genuß der Miesmuscheln aus deutschen Wattenmeer-Gebieten zur paralytischen Muschelvergiftung (PSP) kommen? - Verh. ernährungswiss. Beir. dt. Fischwirt. $28,54-90$.

Gerlach, S. A., 1987. This week's citation classic: On the importance of marine meiofauna for benthos communities. (Oecologia 6, 176-190, 1971.) - Curr. Cont. (Agricult. Biol. environ. Sci.) 18 (41), 18 .

Gerlach, S. A., 1989. Von Seehundsterben und Algenblüten angeregte Gedanken über pathogene Keime im Phytoplankton und über toxische Effekte von mit Phytoplankton vergesellschafteten Bakterien. - Verh. ernährungswiss. Beir. dt. Fischwirt. 32, 82-109.

Gerlach, S. A., 1990. Nitrogen, phosphorus, plankton and oxygen deficiency in the German Bight and in Kiel Bay. - Kieler Meeresforsch. (Suppl.) 7, 1-341.

Graf, G., 1992. Benthic-pelagic coupling: a benthic view. - Oceanogr. mar. Biol. 30, 149-190.

Hempel, G. \& Meyl, A. H. (Eds), 1979. Meeresforschung in den achtziger Jahren. Boldt, Boppard, $80 \mathrm{pp}$.

Künitzer, A., Basford, D., Craeymeersch, J. A., Dewarumez, J. M., Dörjes, J., Duineveld, G. C. A., Eleftheriou, A., Heip, C., Herman, P., Kingston, P., Niermann, U., Rachor, E., Rumohr, H. \& de Wilde, P. A. J., 1992. The benthic infauna of the North Sea: species distribution and assemblages. - ICES J. mar. Sci. 49, 127-143.

Sündermann, J. \& Degens, E. T. (Eds), 1989. Die Nordsee. Wasseraustausch und Schadstoffbelastung. Inst. f. Meeresk., Hamburg, $49 \mathrm{pp}$.

Steele, J., 1974. The structure of marine ecosystems. Harvard Univ. Press, Cambridge, 128 pp. 